УДК 811.161.1'42:821.161.1-1 Тарковский

Каневская О. Б. кандидат педагогических наук, доцент Криворожский педагогический институт ГВУЗ «Криворожский национальный университет»

\title{
СТРУКТУРНЫЕ ОСОБЕННОСТИ СРАВНЕНИЙ
}

В ПОЭТИЧЕСКОЙ РЕЧИ А. А. ТАРКОВСКОГО

У статті пропонується опис структурних типів порівнянь, які $\epsilon$ характерними для ідіостилю А.О. Тарковського. Установлено, що поет, використовуючи повні та неповні порівняння, доволі часто суттєво оновлює їх форму $i$ структуру за допомогою варіювання ознаки або образу; відсутність будь-якого елементу порівняння веде до його багатозначності, можливості декількох трактувань, які дозволяють читачеві брати співучасть у прочесі створення художнього образу та його осмислення. Порівняння поета часто мають мікросюжет, набуваючи іноді символічного значення, закладеного в підтексті, а образи таких порівнянь мають закінчений $і$ самостійний характер.

Ключові слова: порівняння, структурні типи, поетичне мовлення, Арсеній Тарковський.

В статье описаны структурные типь сравнений, характерные для идиостиля А.А. Тарковского. Установлено, что поэт, используя полные и неполные сравнения, нередко существенно обновляет их форму и структуру варьированием признака или образа; отсутствие какого-либо элемента сравнения приводит $\kappa$ его многозначности, возможности нескольких трактовок, позволяющих читателю соучаствовать в процессе 
создания художественного образа и его осмысления. Сравнения поэта часто обладают микросюжетом, приобретая порой символическое значение, заложенное в подтексте, а образы таких сравнений обретают самостоятельный и законченный характер.

Ключевые слова: сравнения, структурные типы, поэтическая речь, Арсений Тарковский.

The article describes the structural types of comparisons that are featured in the individual style of A.A. Tarkovskiy. It is determined that by use of full and partial comparisons the poet quite often significantly renews their shape and structure by varying of sign or image. The lack of any element of comparison commonly results in its polysemy, the possibility of multiple interpretations that allow the reader to participate in the process of creating the artistic image and its comprehension. The comparisons used by the poet often involve a micro-plot, at times gaining a symbolic meaning that lays in the implication, while the images of such comparisons gain independent and complete nature.

Key words: comparisons, structural types, poetic language, Arseniy Tarkovskiy.

Вопрос о художественных сравнениях, об их лингвистической природе представляется нам интересным. Ведь без сравнений, являющихся одним из способов осмысления действительности, одной из форм художественного мышления, не может обойтись ни один язык, а особенно ярко, выразительно и эмоционально они проявляются в языке художественной литературы. Сравнения рассматриваются исследователями (М.А. Бакина, В.П. Вомперский, В.И. Ерёмина, О.Н. Кочинова, Е.А. Некрасова, Г.Н. Основина, Т.А. Тулина и др.) на материале разных языков, творчества разных поэтов и писателей, с разных позиций. Однако своеобразие сравнений в поэтической речи Арсения Александровича Тарковского (1907-1989) не стало еще предметом отдельного изучения.

Сегодня существует целый ряд литературоведческих и лингвистических исследований (Л.Л. Бельская, Т.А. Воронова, Е.В. Джанджакова, Е.Г. Елина, В.В. Кожинов, Н.А. Кузьмина, Д.С. Лихачев, С.А. Мансков, А.М. Марченко, Ю.М. Нейман, П.М. Нерлер, 
И.Г. Павловская, .М. Рунин, С.Н. Руссова, Т.Л. Чаплыгина, Л.П. Черкасова, С.И. Чупринин и др.), в которых определяется статус поэзии А.А. Тарковского, выявляются философско-эстетические и культурологические основания его художественной картины мира, систематизируются языковые особенности лирики поэта, характеризуется его идиостиль и пр. Думается, количество работ об А.А. Тарковском пока не соответствует масштабу личности самобытного поэта. Не хватает исследований, посвященных изучению поэтики его произведений, собственно поэтических текстов, позволяющих выйти к постижению поэтического содержания, глубокой и адекватной их интерпретации. Таким образом, актуальность темы статьи определяется вниманием к особенностям поэтики А.А. Тарковского, а точнее, к одной её стороне сравнению.

Цель статьи - выявить характерные для идиостиля А.А. Тарковского структурные типы сравнений и описать их.

В научной литературе сравнение определяется как «фигура речи, состоящая в уподоблении одного предмета другому, у которого предполагается наличие признака, общего с первым» [Ахманова 1966:430]; содержатся классификации сравнений по разным основаниям: семантике, структуре, синтаксическим и морфологическим признакам, функциям в тексте. Ограниченные рамками статьи проанализируем структурные типы сравнений, вычлененные из поэтических произведений А.А. Тарковского методом сплошной выборки.

Проведенный анализ показал, что поэт активно использует полные (наличие всех компонентов структуры: предмет - образ - признак) и неполные (в структуре отсутствует какой-либо компонент) сравнения.

Широко представлены полные сравнения, чаще всего с лаконичными, нераспространенными компонентами, например: Прозрачный, очевидный, как стекло, / Внезапный смысл [АТ 1982:58]; 
Стою себе, а надо мной навис / Закрученный, как пламя, кипарис [АТ 1982:66]; Мне грешная моя, невинная / Земля моя передает / Свое терпенье муравьиное / И душу крепкую, как йод [АТ 1982:107]. В данных сравнениях выделяются предмет (смысл, кипарис, душа), образ (стекло, пламя, йод) и признак, по которому они сравниваются (прозрачный, закрученныци, крепкий).

Но нередко предмет употребляется вместе с определением, которое распространяет его и усиливает яркость образа: Расцветай же, как лучшая роза / В наилучшем трехмерном плену, / Дорогая житейская проза, / Воспитавшая эту страну [AТ 1982:63]; И по спине пройдет, как дрожь, / Бессмысленная ж⿻ажда чуда [АТ 1982:70].

Особой экспрессией обладают сравнения, в которых два разных предмета располагаются по разные стороны образа: ...и чем-то страшен / Был осторожнный, будто вор, / Хозяйки ящеричий взор; И, чуть расширившись в плечах, / Как вдоль по грифу, второпях / Внезапно раздавалось тело / И доходило до предела / Своих возможностей [AT 1982: 298].

В поэтической речи А. Тарковского встречаются сравнения с распространенным образом: И новая душа плодиться стала, / Как хромосома на стекле предметном [AТ 1982:47]; Мой город - / весь как нотная тетрадь, / Еще не тронутая вдохновеньем [AТ 1982:60]; Я врезался в возраст учета / Не сдавшихся возрасту прав, / Как в город из-за поворота / Железнодорожнный состав [АТ 1982:199]; Сердобольные соседки / Тоже, будто птицы в клетке / На своей засохшей ветке, / Жили у себя в аду [АТ 1982:273].

А также такие сравнения, в которых несколько образов с двух сторон, часто противоположных, характеризуют один и тот же предмет: Так елозит по экрану / C реверансами, как спьяну, / Старый клоун в 
котелке / И, как трезвый, прячет рану / Под жилеткой из пике [AT 1982:151].

Есть сравнения, в которых достаточно распространены и предмет, и образ: Рассчитанный на одного, как номер / Гостиницы - с одним окном, с одной / Кроватью и одним столом, я жил / На белом свете, и моя душа / Привыкла к телу моему [АТ 1982:46].

Характерны для идиостиля А.А. Тарковского сравнения, образы которых получают в тексте развитие и самостоятельный характер, приобретают самоценность. Они во многом символичны и включают в себя большой подтекст: Как первая ладья из чрева океана, / Как жертвенный кувшин выходит из кургана, / Так я по лестнице взойду на mу ступень, / Где будет ждать меня твоя живая тень [АТ 1982:283]; И повели синицы хоровод, / Как будто руки по клавиатуре / Шли от земли до самых верхних нот [AТ 1982:287]; Хореографическим училищем, / Карнавальным молодым вином / Отдает июльская сумятица / Бабочек, играющих с огнем, / Перебрасывающуихся бисером / Со своим крылатым вожаком [АТ 1982:290].

Встречаются и сравнения, в которых, расчленяясь, дробясь, образ варьируется: Когда вступают в спор природа и словарь / И слово силится отвлечься от явлений, / Как слепок от лица, как цвет от светотени, - / Я нищий или цуарь? Коса или косарь? [АТ 1982:224].

А.А. Тарковский часто использует сравнения, в которых образ варьируется, показывая предмет с разных сторон, выделяя различные аспекты его видения поэтом: И - боже мой! - какой-то мотылек, / Как девочка, смеется надо мною, / Как золотого иелка лоскуток [AT 1982:128]; Гром, как державинская ода, / По крыше ямбом грохотал [AT 1982:305]; а также сравнения, в которых второй образ в сравнении уточняет первый: Когда, ещуе спросонок, тело / Мне душу жсло и предо 
мной / Огнем вперед судьба летела / Неопалимой купиной [AТ 1982:145] (уточняется сила творчества, неотвратимость судьбы).

Нередко образ сравнения утраивается: А ниже - бульвары и здания / В кристальном скрипичном напеве, - / Как будущее, как сказание, / Как Будда у матери в чреве [АТ 1982:179].

У поэта есть и такие сравнения, в которых присутствует один образ и два уточняющих друг друга признака: И Европа пред собой / Cмотрит, как самоубийца, / Не мигая, на прибой [АТ 1982:216].

Достаточно часто у Тарковского сравнение строится по образцу: предмет $\rightarrow$ признак $\rightarrow$ образ: Он был по край омыт / Молочно-белым / Стеклом тумана [АТ 1982:287]; ... и толкотня росла, / Как в час прибоя волны океана [АТ 1982:295].

Однако для усиления эмоциональности стиха, подчеркивания смысловой значимости определенного компонента сравнения поэт прибегает к инверсии.

Во-первых, к инверсии предмета и образа (образ $\rightarrow$ предмет): Когда под соснами, как подневольный раб, / Моя душа несла истерзанное тело... [АТ 1982:255]; Как под зимней бурей трава, / Загорелье лица их / Пожелтели от крепких дум [АТ 1982:313]; Стала у него, как шаман / Под венцом, трястись голова [АТ 1982:333]. Предмет сравнения, его основа, часто дается только в самом конце, потому что А.А. Тарковский создает образы, не отталкиваясь от предмета, а через образы идет к предмету, который, в свою очередь, сам порой становился не менее условным и метафорическим, чем образ сравнения, например: Как радугу, степная птица / Расчешет сонное крыло [АТ 1982:51]; Как бутылки, хлопает стрельба [АТ 1982:208].

Интересны сравнения, в которых предмет дистанцируется от образа, что наполняет их глубиной и особым ритмом: назвав предмет, автор вновь возвращается к нему, но уже на новом витке, через образ сравнения: 
Проходит холод запредельный, будто / Какая-то иголка ледяная... [AT 1982:101]; [AT 1982:267].

Во-вторых, к инверсии образа и признака (образ $\rightarrow$ признак): $И$ ласточки над экваториалом, / Как вестницы забвения, снуют [АТ 1982:65]; И араратским кислородом / Продуть холма сухую грудь [AT 1982:254].

В-третьих, к инверсии признак $\rightarrow$ образ $\rightarrow$ предмет: Бьет, как $\boldsymbol{\sigma}$ бубен, в свой кругльй щит [AТ 1982:336]; Завывая, будто шакал, / Взвизгивая, как пес, / Предстал / Перед ними хан Суртайша [AT 1982:340]; а также признак $\rightarrow$ предмет $\rightarrow$ образ: Прянул Актамкер, как стрела... [АТ 1982:330]; И зазубривается, звуча, / Меч ее, как серп [AT 1982:352].

Разнообразно и широко в поэтической речи А.А. Тарковского представлены неполные сравнения, в которых признак восстанавливается по смыслу, особенно если это сравнение традиционно для русского языка и образ, заключенный в нем, в сознании воспринимающего уже несет в себе определенную семантическую нагрузку: Руки у нее - точно лед... [АТ 1982:323]; Гулаим - как пери была. / Речь - неспешная, / Стан стрела, / Рот - наперсток, / Румянец-мак, / Косы - змеи, / Губы каймак, / Зубы - жемчуг, / Стылдивый взор, / На голове - золотой убор [AT 1982:309].

Встречаются сравнения устоявшиеся, привычные и не требующие дополнительной расшифровки, например: $A$ я лежал как труп в гробу [АТ 1982:301]; Словно жжемчуг были слова / У разумниць Сарбиназ [AT 1982:314], а также сравнения, в которых признак не только не подразумевается, а просто не нужен: ... капля малая лазори / Как море синее во взоре [АТ 1982:94] (подчеркивается цвет глаз); А шерсть у него на боках, / Как вата в столетнем халате [АТ 1982:126] (свалявшаяся, грязная). 
Поэт использует и сравнения, в интерпретации которых возможны несколько трактовок: Там, над крышами, как сетка, / Дожюик дышит и дрожит [АТ 1982:44] (дождь сеется над городом; покрыл весь город); Дыханье Рима - как сухие травы [АТ 1982:65] (жара, высохшая степь, старина, древность); Как в речке на дне -/В зеленых потемках Марина [АТ 1982:154] (в глубине, в темноте, в безвыходном положении, без надежды; распространены и предмет, и образ).

В поэтической речи А.А. Тарковского реже встречаются неполные сравнения, в структуре которых отсутствует предмет, имеются только признак и образ: ...бабочкой черной и белой, / Не по-намему дико и смело, / И в мое залетела жилье [АТ 1982:40]; И мушиным жальцем своим / Ты <..> / Угрожсаешь мне... [AT 1982:349].

Часто это или безличные конструкции: Петь бы мне, как noem плотовщик, - / Побольней, потемней, победовей [АТ 1982:105]; или определенно-личные конструкции с глаголами в повелительном наклонении: - В зимней истоме у матери в доме / Спи, как ржсаное зерно в черноземе, / И не заботься о смертном кониее. / - Без сновидений, как Лазарь во гробе, / Спи до весны в материнской утробе, / Выйдешь из гроба в зеленом вение [АТ 1982:275].

Есть конструкции, предмет которых, несмотря на то, что отсутствует в самой структуре сравнения, употребляется в контексте, чаще в препозиции: По льду, по снегу, по жасмину. / По ладони, снега бледней, / Унесла в свою домовину / Половину дущи, половину / Лучшей песни, спетой о ней. / Похвалам земным не доверяясь, / Довершив земной полукруг, / Полупризнанная, как ересь, / Через полог морозный, через / Вихри света - / смотрит на юг [АТ 1982:251].

Неполные сравнения, в структуре которых присутствует только образ, в произведениях А.А. Тарковского не частотны, однако служат для выражения чувств лирического героя и потому становятся 
самодостаточными и независимыми: И это было как преображенье / Простого счастья и простого горя / В прелюдию и фугу для органа [AT 1982:100]. Такие сравнения приобретают в тексте статус самостоятельных, независимых образов и становятся необходимым компонентом в образной системе стихотворения.

Таким образом, А.А. Тарковский, используя полные и неполные сравнения, нередко существенно обновляет их форму и структуру варьированием признака или образа; отсутствие какого-либо элемента сравнения нередко приводит к его многозначности, возможности нескольких трактовок, позволяющих читателю соучаствовать в процессе создания художественного образа и его осмысления. Сравнения поэта часто обладают микросюжетом, приобретая порой символическое значение, заложенное в подтексте, а образы таких сравнений обретают самостоятельный и законченный характер.

\section{БИБЛИОГРАФИЯ}

Ахманова 1966 - Ахманова О.С. Словарь лингвистических терминов / О.С. Ахманова. - М. : Просвещение, 1966. - 305 с.

AT - Тарковский А. А. Избранное : Стихотворения; Поэмы: Переводы. 1929-1979 / Арсений Александрович Тарковский; [вступит. статья С. Чупринина]. - М. : Худож. лит., 1982. - 736 с. 